\title{
COVID-19 in Children with Brain-Based Developmental Disabilities: A Rapid Review
}

Michèle Dugas, $\mathrm{MSc}^{1}$, Valérie Carnovale, $\mathrm{PhD}^{1}$, Andrée-Anne Poirier, $\mathrm{PhD}^{1,2}$ Benoit Mailhot, $\mathrm{PhD}(\mathrm{c})^{1}$, Becky Skidmore, $\mathrm{MLS}^{3}$, Lena Faust, $\mathrm{MSc}^{4,5}$, Carrie Costello ${ }^{6}$, Donna Thomson ${ }^{6}$, Annette Majnemer, OT, PhD, FCAHS ${ }^{7}$, Dan Goldowitz, $\mathrm{PhD}^{8}$, Steven P. Miller, MD, CM, MAS, FRCPC ${ }^{9}$, Annie LeBlanc, $\mathrm{PhD}^{1,10}$.

Affiliations: 1 - VITAM, Centre de recherche en santé durable, CIUSSS de la Capitale-Nationale, Quebec, Canada. 2 Institut national d'excellence en santé et en services sociaux, Quebec, Canada. 3 - Independent Information Specialist, Ottawa, Canada. 4 - Patient-partner (youth) with the CHILD-BRIGHT Network. 5 - Department of Epidemiology, Biostatistics and Occupational Health, McGill University, Montreal, Canada. 6 - Patient-partner (caregiver) with the CHILD-BRIGHT Network. 7 - School of Physical \& Occupational Therapy, Faculty of Medicine, McGill University; Research Institute of the McGill University Health Centre, Montreal, Canada. 8 - Department of Medical Genetics, Centre of Molecular Medicine and Therapeutics, University of British Columbia, Vancouver, Canada. 9 - Department of Paediatrics, The Hospital for Sick Children and the University of Toronto, Toronto, Ontario, Canada. 10 - Department of Family Medicine and Emergency Medicine, Laval University, Quebec, Canada. Corresponding author: Dr. Annie LeBlanc PhD. VITAM, Centre de recherche en santé durable, 2601, chemin de la Canardière (bureau G-2639), Québec (Québec) CANADA, G1J 2G3, Email: annie.leblanc@fmed.ulaval.ca

\begin{abstract}
Background. The prevalence of symptomatic COVID-19 in children remains low to date. In just a few months, COVID-19 has affected millions of people worldwide, and as of the date of this publication, the pandemic continues. Based on the current available evidence, children do not appear to be at higher risk of contracting COVID-19 than adults. However, children with neurological and neuromuscular conditions are vulnerable to the respiratory complications of other viral infections. Objectives. To assess whether children with brain-based developmental disabilities were more likely to develop COVID-19 and have complications or poorer outcomes following infection. Methods. We conducted a two-week rapid review on studies with primary data regarding children aged between zero and 18 years old with brain-based developmental disabilities, or who were at risk of developing such disabilities, with confirmed or suspected COVID-19. We performed our literature searches on April 18, 2020. Results. Our search strategy identified 538 individual records, of which four were included in our review. Of the 50 COVID-19 pediatric patients reported in the included studies, a total of seven children were at risk of developing brain-based disabilities. Symptoms ranged in severity. However, generally, patients were discharged or saw improvements in their symptoms by the end of the study period. No deaths were reported. Discussion. Our study highlights a knowledge gap regarding the impact of COVID-19 in children with brain-based developmental disabilities.
\end{abstract}




\section{Background}

According to the World Health Organization, SARS-CoV-2 has infected close to three million and caused the death of over 200000 individuals worldwide, as of April 26th, 2020 (1). The prevalence of COVID-19 in children remains low to date. Of the 23,082 cases reported in Canada (April 23rd, 2020), 1,055 (4.6\%) were in patients aged 19 years old and under (2). Of those, 14 were hospitalized, and two were admitted to Intensive Care Unit, with no deaths being reported. Data gathered for the U.S. between February 12th, 2020 and April 2nd, 2020 indicated that of the 149,760 cases, $1.5 \%(2,572)$ were children, of which $13 \%$ had underlying conditions, $5.7 \%$ were hospitalized, and included three deaths (3). As of February 11th 2020, China had reported that of 44,672 confirmed cases in mainland China, 965 (2.1\%) were children, with one reported death (4). As of April 24rd, 2020, a total of 150,383 cases were reported in Germany, of which 2,476 (2\%) were under 10 years old, and 6,209 (4\%) were aged between 10 to 19 years old (5). Numbers of hospitalizations and deaths were not available. Finally, as of March 12th, $2020,7,755$ cases were reported in the Republic of Korea, of which 480 (6.2\%) were pediatric, with no deaths being reported (6).

Based on the current available evidence, children do not appear to be at higher risk of contracting COVID-19 than adults (7). However, children with comorbidities may be vulnerable to severe COVID-19 disease (8). Indeed, children with neurological and neuromuscular conditions had an increased risk of respiratory failure when hospitalized with influenza, another viral infection (9). Symptom manifestation in children appears to be milder than in adults (10, 11). Further, the incidence in individuals under 19 years of age has been quite low $(8,10,12)$ and children could even be less susceptible to the COVID-19 disease (7). To the best of our knowledge, no review has searched for the impact of COVID-19 on children with brain-based disabilities affected by COVID-19. 


\section{Objectives}

This rapid review was commissioned by the Strategy for Patient-Oriented Research (SPOR) funded CHILD-BRIGHT Network, an innovative pan-Canadian network that aims to improve life outcomes for children with brain-based developmental disabilities and their families (https://www.child-bright.ca/). Concerned with the potential impact of the novel coronavirus on children with brain-based developmental disabilities, they requested support from the SPOR Evidence Alliance to conduct a rapid review within a two-week period, on the topic. Thus, this review aimed to answer the following questions:

1) Are children with brain-based developmental disabilities more likely to develop COVID19 ?

2) Are children with brain-based developmental disabilities more likely to develop complications due to COVID-19?

3) Are children with brain-based developmental disabilities more likely to have a poorer prognosis once they develop COVID-19?

We engaged with a panel of knowledge users (patients, caregivers, clinicians, decision makers) and researchers from the CHILD-BRIGHT Network throughout the review process, from question development, literature search, interpretation and writing of results, and dissemination of findings. 


\section{Methods}

We conducted the rapid review based on the proposed methodology guide of the Cochrane Rapid Reviews Methods Group (13). We report our results based on the Preferred Reporting Items for Systematic Reviews and Meta-Analyses (PRISMA) Statement (14).

\section{Literature Search}

An experienced medical information specialist developed the search strategies through an iterative process in consultation with the review team and the panel of knowledge users. The MEDLINE strategy was peer reviewed by another senior information specialist prior to execution using the PRESS Checklist (15). Using the OVID platform, we searched Ovid MEDLINE ${ }^{\circledR}$, including Epub Ahead of Print and In-Process \& Other Non-Indexed Citations, Embase Classic+Embase, PsycINFO, Cochrane Database of Systematic Reviews and the Cochrane Central Register of Controlled Trials. We also searched CINAHL (Ebsco) and Web of Science. All searches were performed on April 18 ${ }^{\text {th }}, 2020$.

We used a combination of controlled vocabulary and keywords (e.g., "Coronavirus Infections", "Coronavirus", "Child") for the strategies and adjusted vocabulary and syntax across databases. We initially also included vocabulary and keywords specific to brain-based developmental disabilities but removed them after piloting of that strategy yielded no citations to be included in the review. There were no language restrictions on any of the searches but when possible, animal-only records were removed from the results. We limited results to publication years 2019 to the present. Specific details regarding the strategies appear in Appendix 1.

From the included studies and the reviews identified from our searches, we reviewed reference lists for original studies and cross-referenced them with a list of articles provided by content experts from our knowledge users panel. Considering the fast pace at which information becomes available in the context of COVID-19, we developed a grey literature search strategy in consultation with our experienced medical information specialist, which consisted of preprint articles from SSRN and medRxiv (last consulted April $23^{\text {rd }}, 2020$ ), ongoing trials from the WHO International Clinical Trials Registry Platform (last consulted April $23^{\text {rd }}, 2020$ ), ongoing reviews 
from PROSPERO (last consulted April 23 ${ }^{\text {rd }}, 2020$ ), and Government or Health organizations' websites and reports (consulted between April $17^{\text {th }}$ to April $\left.25^{\text {th }}, 2020\right)$ (Appendix 2).

\section{Eligibility Criteria}

We followed the PECO Framework in establishing eligibility criteria $(16,17)$ (Table 1$)$. We considered any study with primary data that included children aged between zero and 18 with a brain-based developmental disability or at risk of developing such disability with confirmed or suspected COVID-19 (see Appendix 3 for full list).

\section{Table 1. PECO Inclusion Criteria}

\begin{tabular}{|l|l|}
\hline Population (P) & $\begin{array}{l}\text { Children (18 years and under) with brain-based developmental disabilities (e.g., cerebral } \\
\text { palsy, autism, developmental delay, attention deficit hyperactivity disorder, severe } \\
\text { impairments) or at risk of developing brain-based disabilities (e.g., premature, } \\
\text { congenital heart disease/defect). }\end{array}$ \\
\hline Exposure (E) & COVID-19 \\
\hline Comparator (C) & Children with COVID-19 or no comparator \\
\hline Outcomes (O) & Any outcome \\
\hline
\end{tabular}

\section{Study Selection and Extraction}

Four reviewers individually performed screening for titles, abstracts and then full text using pilot-tested standardized forms (25 and five citations respectively for each level of screening). We developed a standardized extraction form that included study (e.g., authors, country, study design) and case characteristics (e.g., type of disability, age), complications, and any outcome reported. Single reviewers extracted data which was then confirmed by a senior reviewer. We resolved discrepancies through discussion.

\section{Risk of Bias Appraisal}

No risk of bias was performed due to the short turnaround timeline.

\section{Synthesis}

We report data using a narrative approach which includes tables of study characteristics and detailed reporting of case characteristics, complications, and outcomes. Our data synthesis focused on providing a descriptive summary to inform knowledge users. 


\section{Literature Search}

\section{Results}

Our search strategy identified 538 individual records. Following the screening of titles and abstracts, we excluded 331 records. After full-text screening of 207 records, we excluded an additional 203 records resulting in a total of four records included in our review (18-21) (Figure 1).

Our grey literature search did not identify any ongoing trials or preprint articles of research regarding children with brain-based developmental disabilities.

\section{Figure 1. Study Flow Diagram}

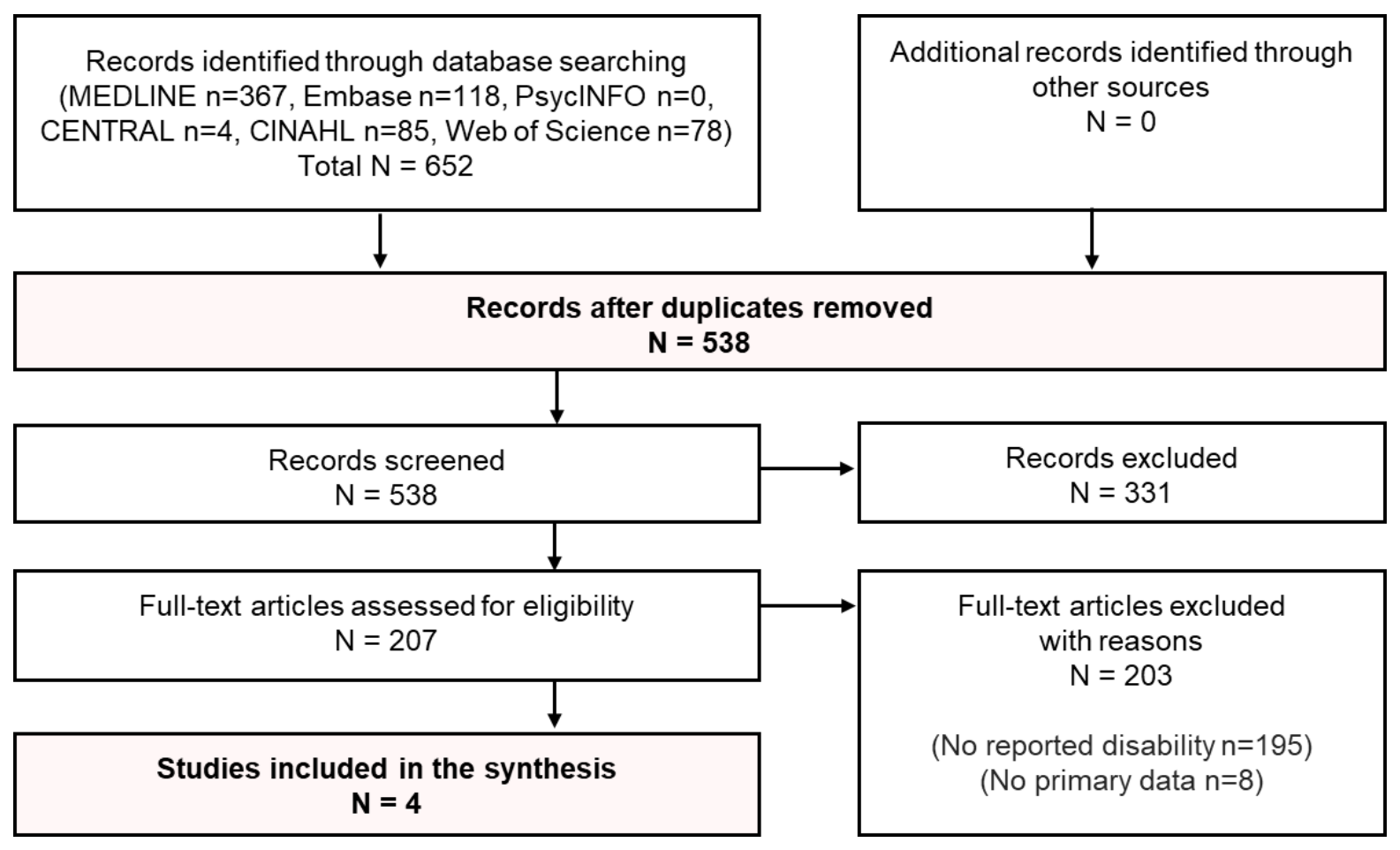

\section{Characteristics of Included Studies}

Of the four included studies, one was a case report (18), one was a cohort study (19), one was a retrospective cross-sectional analysis (20), and one was a retrospective study of medical records (21) (Table 2). Three studies took place in Wuhan, Hubei province, China (19-21) and one in the 
U.S. (18). The four included studies reported on a total of 80 pediatric patients with 50 infected or suspected of being infected.

Table 2. Description of included studies

\begin{tabular}{|l|l|l|l|l|l|}
\hline $\begin{array}{l}\text { Author } \\
\text { (year) }\end{array}$ & Country & Title & Study aims & Study design & Population \\
\hline $\begin{array}{l}\text { Paret } \\
(2020)\end{array}$ & USA & $\begin{array}{l}\text { SARS-CoV-2 infection } \\
\text { (COVID-19) in febrile } \\
\text { infants without } \\
\text { respiratory distress }\end{array}$ & $\begin{array}{l}\text { Reporting of two cases of } \\
\text { COVID-19 in infants }\end{array}$ & Case report & $\begin{array}{l}\text { Infants } \\
\text { (n=2) }\end{array}$ \\
\hline $\begin{array}{l}\text { Zeng } \\
(2020)\end{array}$ & $\begin{array}{l}\text { China } \\
\text { (Wuhan) }\end{array}$ & $\begin{array}{l}\text { Neonatal early-onset } \\
\text { infection with SARS-CoV- } \\
\text { 2 in 33 neonates born to } \\
\text { mothers with COVID-19 } \\
\text { in Wuhan, China }\end{array}$ & $\begin{array}{l}\text { Examining neonatal early- } \\
\text { onset infection with } \\
\text { COVID-19 in 33 neonates } \\
\text { born to mothers with } \\
\text { COVID-19 }\end{array}$ & Cohort study & $\begin{array}{l}\text { Infants } \\
\text { (n=33) }\end{array}$ \\
\hline $\begin{array}{l}\text { Zheng } \\
(2020)\end{array}$ & $\begin{array}{l}\text { China } \\
\text { (Wuhan) }\end{array}$ & $\begin{array}{l}\text { Clinical characteristics of } \\
\text { children with coronavirus } \\
\text { disease 2019 in Hubei, } \\
\text { China }\end{array}$ & $\begin{array}{l}\text { Identifying clinical } \\
\text { characteristics of children } \\
\text { with COVID-19 }\end{array}$ & $\begin{array}{l}\text { Retrospective } \\
\text { cross-sectional } \\
\text { study }\end{array}$ & $\begin{array}{l}\text { Children } \\
\text { (n=25) }\end{array}$ \\
\hline $\begin{array}{l}\text { Xia } \\
(2020)\end{array}$ & $\begin{array}{l}\text { China } \\
\text { (Wuhan) }\end{array}$ & $\begin{array}{l}\text { Clinical and computed } \\
\text { tomography features in } \\
\text { pediatric patients with } \\
\text { COVID-19 infection: } \\
\text { Different points from } \\
\text { adults }\end{array}$ & $\begin{array}{l}\text { Discussing characteristics } \\
\text { of clinical, laboratory, and } \\
\text { chest computed } \\
\text { tomography in pediatric } \\
\text { patients from adults with } \\
\text { COVID-19 }\end{array}$ & $\begin{array}{l}\text { Retrospective study } \\
\text { of medical records }\end{array}$ & $\begin{array}{l}\text { Children } \\
\text { (n=20) }\end{array}$ \\
\hline
\end{tabular}

\section{Characteristics of Cases}

We did not identify any study reporting on children with brain-based developmental disabilities, all included studies reported on children at risk of developing a brain-based developmental disability. Two of the studies included preterm infants $(18,19)$ while the others included children with congenital heart disease or epilepsy $(20,21)$.

Detailed information was only available for three of the four studies (18-20) (Table 3). Symptoms for preterm infants ranged from a single fever to overall mild symptoms $(18,19)$, with one infant developing complications (fetal distress, neonatal respiratory distress syndrome, pneumonia, and suspected sepsis) and requiring resuscitation at birth (19). The preterm infant 
without complications was discharged in stable condition (18) whereas the infant developing complications saw its condition resolve on day 14 of life (19). Children with congenital heart disease expressed symptoms including cough, dyspnea, fever, and diarrhea and required pediatric intensive care with invasive mechanical ventilation (20). Their symptoms were later partially or significantly alleviated (20).

The fourth study identified one patient with epilepsy (resulting from sequela of previous encephalitis) and two with a history of atrial septal defect surgery but no individual information was available (21). Overall, symptoms were mild, and eighteen of the 20 children were cured and discharged with an average stay of 12.9 days (8-20 days).

Table 3. Summary of cases

\begin{tabular}{|c|c|c|c|c|c|c|}
\hline Study & Sex & Age & Diagnostics & Symptoms & Complications & Outcomes \\
\hline $\begin{array}{l}\text { Paret } \\
\text { (USA) }\end{array}$ & $M$ & $56 d$ & $\begin{array}{l}\text { Preterm } \\
\text { (35 weeks) }\end{array}$ & $\begin{array}{l}\text { Fever was } \\
\text { the only } \\
\text { symptom }\end{array}$ & $\mathrm{N} / \mathrm{A}$ & $\begin{array}{l}\text { Patient } \\
\text { discharged in } \\
\text { stable condition }\end{array}$ \\
\hline $\begin{array}{l}\text { Zeng } \\
\text { (China) }\end{array}$ & NR & $0 \mathrm{~d}$ & $\begin{array}{l}\text { Preterm } \\
\text { (31 weeks) }\end{array}$ & $\begin{array}{l}\text { Symptoms } \\
\text { were overall } \\
\text { mild }\end{array}$ & $\begin{array}{l}\text { Fetal distress } \\
\text { Neonatal respiratory } \\
\text { distress syndrome } \\
\text { Pneumonia } \\
\text { Suspected sepsis } \\
\text { Resuscitation was } \\
\text { required at birth }\end{array}$ & $\begin{array}{l}\text { Neonatal } \\
\text { respiratory } \\
\text { distress syndrome } \\
\text { and pneumonia } \\
\text { resolved on day } \\
14 \text { of life }\end{array}$ \\
\hline \multirow[t]{2}{*}{$\begin{array}{l}\text { Zheng } \\
\text { (China) }\end{array}$} & $M$ & $8 \mathrm{mo}$ & $\begin{array}{l}\text { Congenital heart } \\
\text { disease } \\
\text { (malnutrition and } \\
\text { suspected } \\
\text { hereditary } \\
\text { metabolic disease) }\end{array}$ & $\begin{array}{l}\text { Cough } \\
\text { Dyspnea } \\
\text { Fever }\end{array}$ & $\begin{array}{l}\text { Pediatric intensive care } \\
\text { was required with } \\
\text { invasive mechanical } \\
\text { ventilation }\end{array}$ & Partly alleviated \\
\hline & $M$ & $12 \mathrm{mo}$ & $\begin{array}{l}\text { Congenital heart } \\
\text { disease }\end{array}$ & $\begin{array}{l}\text { Fever } \\
\text { Diarrhea } \\
\text { Dyspnea }\end{array}$ & $\begin{array}{l}\text { Pediatric intensive care } \\
\text { was required, with } \\
\text { invasive mechanical } \\
\text { ventilation }\end{array}$ & $\begin{array}{l}\text { Significantly } \\
\text { alleviated }\end{array}$ \\
\hline
\end{tabular}




\section{Discussion}

The prevalence of COVID-19 in children has been reported as being low. However, we were unable to find information regarding the prevalence of this coronavirus in children with brainbased developmental disabilities. We did not identify any study investigating the effects of COVID-19 in children with brain-based disabilities but did identify four studies discussing the coronavirus disease in children considered at risk for disability (preterm infants or children with some pre-existing medical conditions). Although some of the children in the included studies did develop complications, symptoms were reported as being partially or significantly alleviated or resolved, with most patients being discharged from the hospital and no deaths being reported. These results are in accordance with other studies on COVID-19 in children which reported that symptoms in the pediatric population appeared milder than in adults with the occurrence of death being very rare $(11,12,22)$.

Our review highlights the lack of evidence regarding the effects of COVID-19 in children with brain-based disabilities and those with at-risk conditions. Indeed, it appears as though this specific population has been overlooked. The lack of data could be due to the low occurrence rates as well as the milder symptoms which have previously been reported in children $(11,12$, 22). In addition, it is possible that due to their milder or absent symptoms, these cases simply do not get reported. However, clinical guidelines from the Centers for Disease Control and Prevention (CDC) clearly state that individuals of any age with underlying conditions, including congenital heart disease, may be at higher risk of developing moderate to severe symptoms from COVID-19 (23). Moreover, UNICEF warns that children with underlying disabilities may be at greater risk of developing complications (24). More data, including the presence of brainbased disabilities and other at-risk conditions in children, are required to have a better understanding of the clinical impacts of COVID-19 on these potentially more vulnerable populations. With that goal in mind, one ongoing review is currently examining comorbidities in the adult and pediatric populations (25).

\section{Limitations}

Our rapid review has limitations. Due to our study design, screenings and data extractions were performed by single reviewers. However, we did perform pilot-testing for each review form to optimize consistency between reviewers. Further, despite our best efforts to identify all relevant 
studies or relevant documentation, it is possible that some were missed due to the rapid flow at which new information becomes available.

\section{Implications for Practice and Policy}

Our rapid review has identified knowledge gaps in the literature regarding the effects of COVID19 in children with developmental brain-based disabilities, and those at risk of developing such disabilities. Without data regarding children and high-risk populations, it is difficult for decisionmakers to determine the best course of action not only for medical treatment, but also the reintegration of children with disabilities to school and the community with regards to the eventually alleviated confinement measures.

\section{Acknowledgements}

The authors would like to thank the panel of knowledge users for their support throughout this review.

\section{Declaration of conflicting interests}

The authors have no conflict of interests to declare.

\section{Funding}

This review was funded by the CHILD-BRIGHT Network and the SPOR Evidence Alliance. Both Networks are supported by the Canadian Institutes of Health Research under Canada's Strategy for Patient-Oriented Research (SPOR) Initiative. 
medRxiv preprint doi: https://doi.org/10.1101/2020.05.01.20088021; this version posted May 6, 2020. The copyright holder for this preprint (which was not certified by peer review) is the author/funder, who has granted medRxiv a license to display the preprint in perpetuity. It is made available under a CC-BY-NC-ND 4.0 International license .

\section{References}

1. World Health Organization. Coronavirus disease 2019 (COVID-19). 202026 April 2020.

2. Health Canada - Updated: April 23. Daily Epidemiology Update. 2020 April 23, 2020.

3. Team CC-R. Coronavirus Disease 2019 in Children - United States, February 12-April 2, 2020. MMWR Morb Mortal Wkly Rep. 2020;69(14):422-6.

4. The Novel Coronavirus Pneumonia Emergency Response Epidemiology Team. The Epidemiological Characteristics of an Outbreak of 2019 Novel Coronavirus Diseases (COVID-19) China. China CDC Weekly. 2020;2(8):113-22.

5. Institute RK. Coronavirus Disease 2019 (COVID-19) Daily Situation Report (English Version) Germany2020 [

6. COVID-19 National Emergency Response Center EaCMT, Korea Centers for Disease Control and Prevention. Coronavirus Disease-19: The First 7,755 Cases in the Republic of Korea. Osong Public Health Res Perspect. 2020;11(2):85-90.

7. Lee P-I, Hu Y-L, Chen P-Y, Huang Y-C, Hsueh P-R. Are children less susceptible to COVID-19? Journal of Microbiology, Immunology, and Infection. 2020.

8. Yi J, Xiaoxia L, Runming J, al. e. Novel coronavirus infections: standard/protocol/guideline recommendations for the diagnosis, prevention and control of the 2019 novel coronavirus infection in children (the second edition). Chinese Journal of Applied Clinical Pediatrics. 2020;35(2):143-50.

9. Keren R, Zaoutis TE, Bridges CB, Herrera G, Watson BM, Wheeler AB, et al. Neurological and neuromuscular disease as a risk factor for respiratory failure in children hospitalized with influenza infection. Jama. 2005;294(17):2188-94.

10. Wu Z, McGoogan JM. Characteristics of and important lessons from the coronavirus disease 2019 (COVID-19) outbreak in China: summary of a report of 72314 cases from the Chinese Center for Disease Control and Prevention. Jama. 2020.

11. Qiu H, Wu J, Hong L, Luo Y, Song Q, Chen D. Clinical and epidemiological features of 36 children with coronavirus disease 2019 (COVID-19) in Zhejiang, China: an observational cohort study. The Lancet Infectious Diseases. 2020.

12. Brodin P. Why is COVID-19 so mild in children? Acta Paediatrica. 2020.

13. Garrity C, Gartlehner G, Kamel C, King VJ, Nussbaumer-Streit B, Stevens A, et al. Cochrane Rapid Reviews. Interim Guidance from the Cochrane Rapid Reviews Methods Group; 2020. 14. Moher D, Liberati A, Tetzlaff J, Altman DG, The PG. Preferred Reporting Items for Systematic Reviews and Meta-Analyses: The PRISMA Statement. PLOS Medicine. 2009;6(7):e1000097. 15. McGowan J, Sampson M, Salzwedel DM, Cogo E, Foerster V, Lefebvre C. PRESS Peer Review of Electronic Search Strategies: 2015 Guideline Statement. Journal of clinical epidemiology. 2016;75:40-6.

16. Huang X, Lin J, Demner-Fushman D. Evaluation of PICO as a knowledge representation for clinical questions. AMIA Annu Symp Proc. 2006;2006:359-63.

17. Schardt C, Adams MB, Owens T, Keitz S, Fontelo P. Utilization of the PICO framework to improve searching PubMed for clinical questions. BMC medical informatics and decision making. 2007;7:16.

18. Paret M, Lighter J, Pellett Madan R, Raabe VN, Shust GF, Ratner AJ. SARS-CoV-2 infection (COVID-19) in febrile infants without respiratory distress. Clinical Infectious Diseases. 2020. 19. Zeng L, Xia S, Yuan W, Yan K, Xiao F, Shao J, et al. Neonatal early-onset infection with SARSCoV-2 in 33 neonates born to mothers with COVID-19 in Wuhan, China. JAMA pediatrics. 2020. 
medRxiv preprint doi: https://doi.org/10.1101/2020.05.01.20088021; this version posted May 6, 2020. The copyright holder for this preprint (which was not certified by peer review) is the author/funder, who has granted medRxiv a license to display the preprint in perpetuity.

It is made available under a CC-BY-NC-ND 4.0 International license.

20. Zheng F, Liao C, Fan Q-h, Chen H-b, Zhao X-g, Xie Z-g, et al. Clinical characteristics of children with coronavirus disease 2019 in Hubei, China. Current Medical Science. 2020:1-6.

21. Xia W, Shao J, Guo Y, Peng X, Li Z, Hu D. Clinical and CT features in pediatric patients with COVID-19 infection: Different points from adults. Pediatric pulmonology. 2020.

22. Ludvigsson JF. Systematic review of COVID-19 in children show milder cases and a better prognosis than adults. Acta Paediatrica. 2020.

23. Centers for Disease Control and Prevention. People Who Are at Higher Risk for Severe Illness: Center for Disease Control and Prevention,; [updated April 15, 2020. Available from: https://www.cdc.gov/coronavirus/2019-ncov/need-extra-precautions/people-at-higherrisk.html.

24. UNICEF. COVID-19 response: Considerations for Children and Adults with Disabilities. 2020. Available from: https://www.unicef.org/disabilities/files/COVID-

19_response_considerations_for_people_with_disabilities_190320.pdf

25. Islam MA, Kundu S, Alam SS. Prevalence of symptoms and comorbid conditions in novel coronavirus (COVID-19)-infected adult and paediatric patients: a systematic review and metaanalysis of first three-month data of the outbreak. PROSPERO.

2020;CRD42020176341(https://www.crd.york.ac.uk/prospero/display_record.php?ID=CRD4202 0176341). 